\title{
Analysis of differentially expressed gene fragments in the head kidney of lipopolysaccharide-stimulated Malabar grouper (Epinephelus malabaricus)
}

\author{
Análisis de fragmentos de gen expresados diferencialmente en el riñón cefálico \\ del mero malabárico (Epinephelus malabaricus) estimulado con lipopolisacáridos
}

\author{
ZY Xie ${ }^{\mathrm{a}}$, XD Xu ${ }^{\mathrm{a}}$,, SF Wang ${ }^{\mathrm{a}}$, Y Cai ${ }^{\mathrm{a}}$, YC Zhou ${ }^{\mathrm{a}^{*}}$

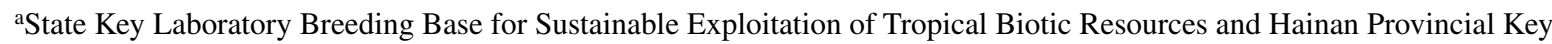 \\ Laboratory for Tropical Hydrobiology and Biotechnology, Hainan University, Haikou, P. R. China. \\ ${ }^{b}$ Fisheries Research Institute of Jiangxi Province, Nanchang, P. R. China.
}

\begin{abstract}
RESUMEN
Se estudiaron los efectos inmunológicos y el mecanismo molecular preliminar de lipopolisacáridos (LPS) en el mero malabárico (Epinephelus malabaricus). El mero se inyectó intraperitonealmente dos veces (con 7 días de diferencia) con $4 \mathrm{mg} / \mathrm{kg}^{-1}$ peso corporal de LPS provenientes de Escherichia coli (grupo de prueba, probadores) o solución de tampón fosfato $\mathrm{pH}$ 7,2 (grupo control, conductores). Veintiocho días después, la actividad media de antibacterianos, lisozima y polifenol oxidasa del suero mostraron valores de probador de $0,228,0,032$ y $21,8 \mathrm{U} / \mathrm{ml} \mathrm{x}$ min, respectivamente, mientras que los valores de controlador fueron 0,200, 0,015 y 15,5 U/ml x min. Se elaboró una librería subtractiva de cDNA del riñón cefálico estimulado con LPS de mero malabárico utilizando hibridación substractiva por supresión. Se seleccionaron y secuenciaron 376 clones de fragmentos de genes expresados de probadores específicos, y se obtuvieron 326 EST calificados. Después de una búsqueda con los programas BLASTn y BLASTx, 312 ESTs mostraron gran similitud para 13 fragmentos de genes (14 ESTs no se asemejaron a ninguno de los genes en el GenBank). De los 13 fragmentos, dos (15,4\%) estaban relacionados con inmunodefensa (factor 2 regulador de interferón-proteína de unión 2-A y complejo T de proteínas 1-theta); cinco (38,5\%) estuvieron relacionados con la transcripción o la traducción; uno (7,7\%) estuvo involucrado en el metabolismo (proteína CT054); dos (15,4\%) codificarían homologoproteína de diferenciación, leucemia mieloide y la proteína 3 que contiene el dominio parche G; y tres $(23,1 \%)$ eran genes de transporte de oxígeno que codifican la cadena $\alpha$ de hemoglobina, la cadena $\beta$ de la hemoglobina y de la cadena pesada de ferritina. Los resultados mostraron que LPS podrían mejorar significativamente la inmunidad innata y regular la expresión de genes relacionados con la inmunidad, la producción de energía celular, el crecimiento, metabolismo o la resistencia al estrés en mero malabárico. Además, LPS pueden ser utilizados como un inmunoestimulante eficaz para esta especie, proporcionando una visión de los mecanismos de los efectos de LPS en animales acuáticos a niveles serológicos y moleculares.
\end{abstract}

Palabras clave: Epinephelus malabaricus, lipopolisacárido (LPS), hibridación subtractiva, inmunoestimulate.

\section{SUMMARY}

The immunological effect and preliminary molecular mechanism of lipopolysaccharide (LPS) on Malabar grouper (Epinephelus malabaricus) were studied. The grouper was injected intraperitoneally twice (7 days apart) with $4 \mathrm{mg} \mathrm{kg}^{-1}$ body weight of LPS from Escherichia coli (test group; testers) or pH 7.2 phosphate buffer solution (control group; drivers). Twenty-eight days later, the mean antibacterial, lysozyme and polyphenol oxidase activities of the serum showed tester values of $0.228,0.032$ and $21.8 \mathrm{U} / \mathrm{ml} \times \mathrm{min}$ respectively, and driver values of $0.200,0.015 \mathrm{and} 15.5 \mathrm{U} / \mathrm{ml} \times \mathrm{min}$. A subtracted cDNA library from the head kidney of LPS-stimulated Malabar grouper was constructed using suppression subtractive hybridization. A total of 376 clones from tester-specific expressed gene fragments were selected and sequenced, and 326 qualified expressed sequence tags (ESTs) were obtained. After searching with the BLASTn and BLASTx programs, 312 ESTs showed great similarity for 13 gene fragments (14 ESTs did not match any genes in the Genbank). Out of these 13 fragments two (15.4\%) were related to immune defense (interferon regulatory factor 2-binding protein 2-A and T-complex protein 1-theta); five (38.5\%) were related to transcription or translation; one (7.7\%) was involved in metabolism (CT054 protein); two (15.4\%) might encode myeloid leukemia differentiation protein homologue and $\mathrm{G}$ patch domain-containing protein 3; and three (23.1\%) were oxygen transport genes that encode haemoglobin $\alpha$ chain, haemoglobin $\beta$ chain and ferritin heavy chain. Results showed that LPS could significantly improve innate immunity and regulate the expression of genes related to immunity, cellular energy production, growth, metabolism and/or stress-resistance in Malabar grouper. Also, LPS could be used as an effective immunostimulant for this species and provided an insight to the mechanisms of the effects of LPS on aquatic animals at serological and molecular levels.

Key words: Epinephelus malabaricus, lipopolysaccharide (LPS), subtractive hybridization, immunostimulant.

\section{INTRODUCTION}

Groupers are regarded as high-quality seafood and cultured widely in Southeast Asia. Malabar grouper,

Accepted: 08.05.2014.

* 58 Renmin Road, Haikou 570228, P. R. China; zychnu@ 163.com
Epinephelus malabaricus (Bloch and Schneider 1801), is one of the most cultured groupers in China due to its desirable taste and high economic value. The rapid development of Malabar grouper culture meant that diseases caused by bacteria, viruses and parasites became becoming increasingly problematic. However, previous studies on Malabar grouper focused mainly on its culture technique, nutrition and physiology (Lin and Shiau 2005, Tuan and 
Williams 2007), and little information about its immunology or molecular immunology is available.

Lipopolysaccharide (LPS), an essential component of the cell wall of Gram-negative bacteria, can effectively improve the non-specific immunity of aquatic and terrestrial animals and is widely used as an immunostimulant to control their infectious diseases (Nya and Austin 2010). Jian et al (2004) reported that, after injection of LPS for 28 days, the immunity of many aquatic animals was significantly improved. Savan and Sakai (2002) and Wang and Wu (2007) detected the differentially expressed genes in yellow grouper (Epinephelus awoara) and common carp (Cyprinus carpio) after stimulation with LPS. In addition, it also could induce the differential expression of immunoregulatory genes in murine macrophages and human monocytes (Barber et al 1995) and the expression of cytokines and phase proteins in fish cells in vitro (Neumann et al 1995, MacKenzie et al 2003).

Several polymerase chain reaction (PCR)-based methods, including differential display-PCR, representational difference analysis, RNA fingerprinting by random primed PCR, cDNA-amplified fragment length polymorphism and suppression subtractive hybridization (SSH), have been used to analyse differential gene expression (Liang and Pardee 1992, Lisitsyn and Wigler 1993, Perucho et al 1995, Diatchenko et al 1996, Gabriëls et al 2006). Of all these methods, SSH is considered an ideal for obtaining low abundant differentially expressed cDNAs because it has the advantages of high level enrichment, low background noise and normalised abundance of cDNA in the subtracted mixture. To assess the immunological effects of LPS on Malabar grouper and study the molecular mechanisms underlying the stimulation process, three immunological indices of serum were assayed and differentially expressed genes from the head kidney of Malabar grouper were identified after being stimulated with LPS in this study.

\section{MATERIAL AND METHODS}

\section{ANIMAL MAINTENANCE AND SAMPLE PREPARATION}

Malabar groupers weighing 50 $\pm 10 \mathrm{~g}$ were obtained from a fish hatchery in Wenchang City, Hainan Province, China. Prior to the experiments, fish were maintained for a week at $28^{\circ} \mathrm{C}$ in tanks with a circulating seawater system and fed daily with artificial pellets. Ten fish from the test groups (testers) were injected intraperitoneally with $4 \mathrm{mg}$ $\mathrm{kg}^{-1}$ body weight of LPS (Xu et al 2010) from Escherichia coli (Sigma, USA), while ten fish from the control group were injected with phosphate buffer solution (PBS; pH7.2) (drivers). To improve the effect of immunization, one week after the first injection all groupers were injected again with the same solution as before. Twenty eight days after the second injection, fish were anesthetised. Blood was extracted with a sterile syringe from the caudal vein, placed into $1.5 \mathrm{~mL}$ centrifugation tubes and kept at $-4{ }^{\circ} \mathrm{C}$ overnight. Then, the clot was centrifuged at $112 \times \mathrm{g}$ for 10 $\mathrm{min}$. Serum was collected and stored in sterile $1.5 \mathrm{~mL}$ tubes at $-20{ }^{\circ} \mathrm{C}$. Meanwhile, head kidneys were separated and frozen in liquid nitrogen, then stored at $-80^{\circ} \mathrm{C}$ for further use. All animal challenges were carried out following IACUC approved protocols of Hainan University.

\section{ASSAY OF ANTIBACTERIAL ACTIVITY}

To detect the antibacterial activity (Ua) of the serum from Malabar groupers, a modified turbidimetric growth assay method was performed according to Noga et al (1994). After being incubated overnight in trypticase soy broth (TSB) supplemented with $2 \% \mathrm{NaCl}$, Vibrio alginolyticus ATCC 33787 was washed and diluted with PBS (pH 7.2; supplemented with $2 \% \mathrm{NaCl}$ ) to an absorbance at $570 \mathrm{~nm}$ of $0.3-0.5$. Then, in separate test tubes $2 \mu \mathrm{L}$ of each serum was added to $3 \mathrm{~mL}$ of $V$. alginolyticus suspension. One milliliter of each mixture was immediately transferred into $1.0 \mathrm{~cm}$ path-length cuvettes and the absorbance at $570 \mathrm{~nm}$ was measured $\left(\mathrm{A}_{0}\right)$. The test tubes were placed in a water bath at $25 \pm 1{ }^{\circ} \mathrm{C}$ for $30 \mathrm{~min}$, before being transferred to an ice-cold water bath to stop the reactions. Absorbance values $\left(\mathrm{A}_{\text {end }}\right)$ were recorded and Ua was calculated for each sample using the following formula: $\mathrm{Ua}$ $=\left[\left(\mathrm{A}_{0}-\mathrm{A}_{\text {end }}\right) / \mathrm{A}_{\text {end }}\right]{ }^{1 / 2}$. Mean Ua of the test group and control group were calculated and a Student's $t$ test was performed to evaluate their difference significant using the Origin 7.5 software (OriginLab, USA). Differences were considered to be statistically significant when $\mathrm{P}<0.05$.

\section{ASSAY OF LYSOZYME ACTIVITY}

Lysozyme activity (Ul) was determined using a method modified from Parry et al (1965) and Zhang et al (2010). Micrococcus lysodeikticus (Sigma, USA) was added to PBS (pH6.4) to obtain an absorbance at $570 \mathrm{~nm}$ of 0.3. Three milliliters of M. lysodeikticus suspension was aliquoted into separate test tubes in an ice-cold water bath, and $50 \mu \mathrm{L}$ of each serum sample was added. Each suspension was mixed and $\mathrm{A}_{0}$ at $570 \mathrm{~nm}$ was tested immediately. Test tubes were placed in a water bath at $25 \pm 1^{\circ} \mathrm{C}$ for $30 \mathrm{~min}$, before being transferred to an ice-cold water bath to stop the reactions. The $\mathrm{A}_{\text {end }}$ was assayed and $\mathrm{Ul}$ was calculated according to the following formula: $\mathrm{Ul}=\left(\mathrm{A}_{0}-\mathrm{A}_{\text {end }}\right) / \mathrm{A}_{\text {end }}$. Mean Ul of the test group and control group were calculated and their difference significant was evaluated as above.

\section{ASSAY OF POLYPHENOL OXIDASE ACTIVITY}

Polyphenol oxidase (PPO) activity was determined using a modified spectrophotometric method based on the initial rate of increase in absorbance at $490 \mathrm{~nm}$ (Ashida 1971, Gundogmaz et al 2003). One hundred microlitter of $0.01 \mathrm{~mol} \mathrm{~L}^{-1} \mathrm{~L}$-dihydroxyphenyl-alanine (L-DOPA; Sigma, USA) and $2.8 \mathrm{~mL}$ of $0.1 \mathrm{~mol} \mathrm{~L}^{-1} \mathrm{PBS}$ (pH 6.0) was added to $100 \mu \mathrm{L}$ of each serum sample. The suspensions were mixed in 4-mL quartz cuvettes and the absorbances at $490 \mathrm{~nm}$ were recorded at $25 \pm 1{ }^{\circ} \mathrm{C}$ at $30 \mathrm{~s}$ intervals for 10 min using a UV-visible spectrophotometer (Shimadiu 
UV2450, Japan). The instrument was zeroed using the mixture without the serum. One unit of PPO activity was defined as the amount of enzyme in $1 \mathrm{~mL}$ of serum that caused an increase in absorbance at $490 \mathrm{~nm}$ of 0.001 per min at $25^{\circ} \mathrm{C}$ in the linear portion of the curve. Mean PPO activity of the test group and control group were calculated and their significant difference was evaluated as above.

\section{CONSTRUCTION OF A SSH LIBRARY AND ANALYSIS OF SUBTRACTION EFFICIENCY}

Total RNA was extracted from the head kidneys of the drivers and testers using TRIZOL reagent (Invitrogen, USA) according to the manufacturer's instructions. RNA integrity was checked using $1 \%$ formaldehyde agarose gel. Total mRNA was purified by PolyATtract ${ }^{\circledR}$ mRNA Isolation System III (Promega, USA) according to the protocol of the manufacturer. cDNA synthesis and SSH were performed using the PCR-Select ${ }^{\mathrm{TM}}$ cDNA Subtraction kit (Clontech, USA) according to the manufacturer's instructions. The tester cDNA for control subtraction was constructed by mixing the control skeletal muscle cDNA with $\varphi$ X174/Hae III DNA. The resulting subtracted cDNA fragments were amplified, ligated into the pMD-19 vector (Takara, Japan) and transformed into E. coli strain JM109 (Takara, Japan). Positive clones were selected by blue/white spot screening and colony PCR amplifications, which were performed with nested PCR primers 1 (5'-DTCGAGCGGCCGCCCGGGCAGGTD-3') and 2R (5'-DAGCGTGGTCGCGGCCGAGGTD-3').

To evaluate the efficiency of adaptor ligation, the relative amount of the constitutively expressed housekeeping gene coding glyceraldehyde-3-phosphate dehydrogenase (GAPDH) was compared in subtracted and unsubtracted cDNA after 18, 23, 28 and 33 cycles of PCR. PCR reactions were carried out using GAPDH gene-specific primers (forward primer: 5'-ACCTGATGCTCCAATGTTT-3'; reverse primer: 5'-AGCAACTGGCACCCTGAA-3').

Southern dot blotting was performed with DIG High Prime DNA Labeling and Detection Starter Kit II (Roche, Germany). The DIG-labeled driver DNA probes were generated with DIG-High Prime according to the random primed labeling technique. The PCR products from positive clones were hybridised into the probes. The transfer of DNA to the nylon membrane (Promega, USA) and hybridisation conditions were performed with standard methods. The clones of negative blots were considered to represent the subtractive clones that contained the unique tester fragments, and these were sequenced using M13 universal primers at Shenzhen Huada Gene Institute (Shenzhen, Guangdong Province, China).

\section{DATABASE ANALYSIS}

Vector contamination sequences were removed using the Cross match program. Then, sequences were compared against the non-redundant database at the National Center for Biotechnology Information ${ }^{1}$ using the BLASTn and BLASTx programs (threshold E-value $\leq 1 \mathrm{E}-5$ ).

\section{REAL-TIME PCR}

Real-time PCR was performed in a total volume of $20 \mu \mathrm{l}$ containing $0.5 \mu \mathrm{l} 10 \mu \mathrm{M}$ each primer, $2 \mu \mathrm{l}$ diluted cDNA and $9 \mu \mathrm{l} 2$ X SYBR Green Master Mix Reagent (Bio-Rad). Reactions were run using the following cycling parameters: $95^{\circ} \mathrm{C}$ for $2 \mathrm{~min}, 40$ cycles of $95^{\circ} \mathrm{C}$ for $15 \mathrm{~s}$, $55^{\circ} \mathrm{C}$ for $15 \mathrm{~s}$ and $68^{\circ} \mathrm{C}$ for $30 \mathrm{~s}$. The final extension was performed at $72{ }^{\circ} \mathrm{C}$ for $5 \mathrm{~min}$. Primer sequences (table 1) were designed with Primer-Premier 5 software based on the sequences of the selected clones.

\section{STATISTICAL ANALYSIS}

Arithmetic mean \pm standard error (SE) were used to represent the values of each measured parameter. The software programme SPSS (v. 16.0) for Windows was used for the analysis.

\section{RESULTS}

\section{ANTIBACTERIAL, LYSOZYME AND POLYPHENOL OXIDASE} ACTIVITY

Mean Ua, Ul and PPO activities in the serum of fish in the test group were $0.228 \pm 0.0104,0.032 \pm 0.0036$ and $21.8 \pm 0.9539 \mathrm{U} / \mathrm{ml} \times \mathrm{min}$, respectively, while the values in the control group were $0.200 \pm 0.0072,0.015 \pm 0.0030$, $15.5 \pm 0.5196 \mathrm{U} / \mathrm{ml} \times \min$ (figure 1). All the $\mathrm{Ua}, \mathrm{Ul}$ and $\mathrm{PPO}$ activities were significantly different $(\mathrm{P}<0.01)$ between the test group and the control group.

\section{CONSTRUCTION OF A SSH CDNA LIBRARY AND ANALYSIS OF SUBTRACTION EFFICIENCY}

Products of the second PCR amplification were separated by electrophoresis and stained with ethidium bromide (figure 2). After the second PCR amplification, the smear of the subtracted cDNA was lighter than that of the unsubtracted products, which suggested fewer cDNA types in the subtracted cDNA than in the control (figure 2, lanes 4 and 5). The PCR products of the subtracted cDNA occurred as a smear consisting of a series of fine bands ranging from $0.5-1 \mathrm{~kb}$ (figure 2 , lane 4 ). The PCR control subtracted cDNA (figure 2, lane 3 ) provided a positive PCR control consisting of the skeletal muscle sample and contained a successful subtracted mixture of Hae IIIdigested $\varphi$ X174 DNA. The secondary PCR products of the subtracted tester cDNA for control subtraction (figure 2, lane 1) mostly contained DNA fragments corresponding to the $\varphi \mathrm{X} 174 /$ Hae III digest, which was the same pattern

\footnotetext{
www.ncbi.nlm.nih.gov
} 
Table 1. Primers used for real-time RT-PCR.

Partidores usados para RT-PCR en tiempo real.

\begin{tabular}{|c|c|c|c|}
\hline Gene name & Forward primer (5'-3') & Reverse primer (5'-3') & Product size (bp) \\
\hline $\begin{array}{l}\text { Interferon regulatory factor 2-bind- } \\
\text { ing protein }\end{array}$ & CTGGTCGGCTCCAATGTG & GGGCTTGCTGGGTGATTT & 203 \\
\hline T-Complex protein 1-theta & TAAATCACCCAGCAAGCC & AGCAAACAGTGCCATCCA & 306 \\
\hline Haemoglobin beta chain & ATGTGGTCTACAATGCCTCC & ATGCTGACTTCTTCTGGGT & 213 \\
\hline Haemoglobin alpha chain & ATCGCCCTTCCCAACAGT & CGTATCCAGAGCCTTCGT & 290 \\
\hline Ferritin heavy chain & ACCCTAATAATCGCTCTG & TCCTGGTGGTAGTTCTGT & 221 \\
\hline $\begin{array}{l}\text { Eukaryotic translation elongation } \\
\text { factor-2 }\end{array}$ & ATTAGACGCCACAAGCAA & GAATGAGGCAAGAGCAAA & 139 \\
\hline $\begin{array}{l}\text { Procollagen C-endopeptidase } \\
\text { enhancer } 1 \text { precursor }\end{array}$ & GCAGAGGTGCCTACTACAT & CAGGGTTGGTTCTGGATA & 133 \\
\hline Ribosomal protein S28 & CAGGTCCGTGTTGAGT & GAGGTCTTCTGCGTCA & 178 \\
\hline Ribosomal protein L3 & GGCAGAAGAAGTCTCACC & GCCAGGCACCAATACA & 252 \\
\hline 40S ribosomal protein $S 8$ & GTGGTCTACAATGCCTCC & TCTTCTGGGTCCTCTTCG & 202 \\
\hline CT054 protein & AGGGTCAGGACAAACAGG & TGGCTTGGGTCAATGCTC & 310 \\
\hline $\begin{array}{l}\text { Myeloid leukemia differentiation } \\
\text { protein homologue }\end{array}$ & AGAGGGACTGGCTGGTTA & ACGTGGAGGAATTGTTGC & 218 \\
\hline G patch domain containing 3 & TCGTGTTTGGTTGCCGTCTC & GGGCTGGAAGGATGGTGAA- & 230 \\
\hline
\end{tabular}
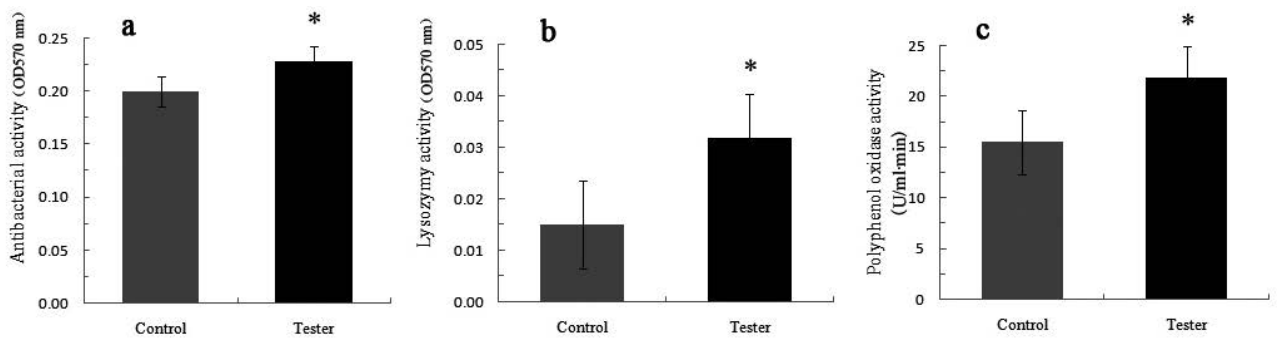

Figure 1. Effects of E. coli LPS on the antibacterial activity (a), lysozyme activity (b) and polyphenol oxidase activity (c) of Malabar grouper serum. Values are mean \pm S.D.; $\mathrm{n}=10$. $\mathrm{P}<0.01$.

Efectos de LPS de E. coli sobre la activiadad antibacterial (a), actividad de lisosoma (b) y actividad de polifenol oxidasa del serum de mero malabárico. Valores corresponden al promedio \pm D.S.; $\mathrm{n}=10 . * \mathrm{P}<0,01$.

as the control subtraction provided in the kit (figure 2, lane 3). It confirmed that the experimental subtracted processes had worked efficiently.

The results of blue/white spot screening showed that approximately $96 \%$ of the transformants contained inserts. Totally 2664 positive clones were obtained, and subsequent colony PCR revealed that the sizes of the inserts ranged from $200-1000 \mathrm{bp}$. PCR products from 376 clones gave negative spots in the dot blotting. Thus, a putative LPS-stimulated subtracted cDNA library from the head kidney of Malabar grouper was successfully constructed and it consisted of 376 clones containing tester-specific expressed gene fragments.

\section{ESTS ANALYSIS}

A total of 376 tester-specific cDNA clones from the head kidney of LPS-stimulated Malabar grouper were sequenced. After removing the vector sequence and trimming the poor-quality sequences, 326 qualified ESTs were obtained (table 2). In these qualified ESTs, 312 ESTs showed great similarity to 13 previously reported gene fragments, but the remaining 14 ESTs did not share any matches in the gene database. A summary of the identified genes and Genbank accession numbers for the ESTs are shown in table 2. Two genes related to immune defense, namely interferon regulatory factor 2-binding protein 2-A and T-Complex protein 1-theta, were identified. Three genes associated with oxygen transport were cloned (haemoglobin $\alpha$ chain, haemoglobin $\beta$ chain and ferritin heavy chain). Five genes related to transcription and translation were identified. One clone corresponded to the $\mathrm{CT} 054$ protein, a metabolism related protein. Finally, two genes that might encode myeloid leukemia differentiation protein homologue and $\mathrm{G}$ patch domain-containing protein 3 were also identified. The most frequently identified clones corresponded to haemoglobin $\beta$ chain $(n=268)$. 


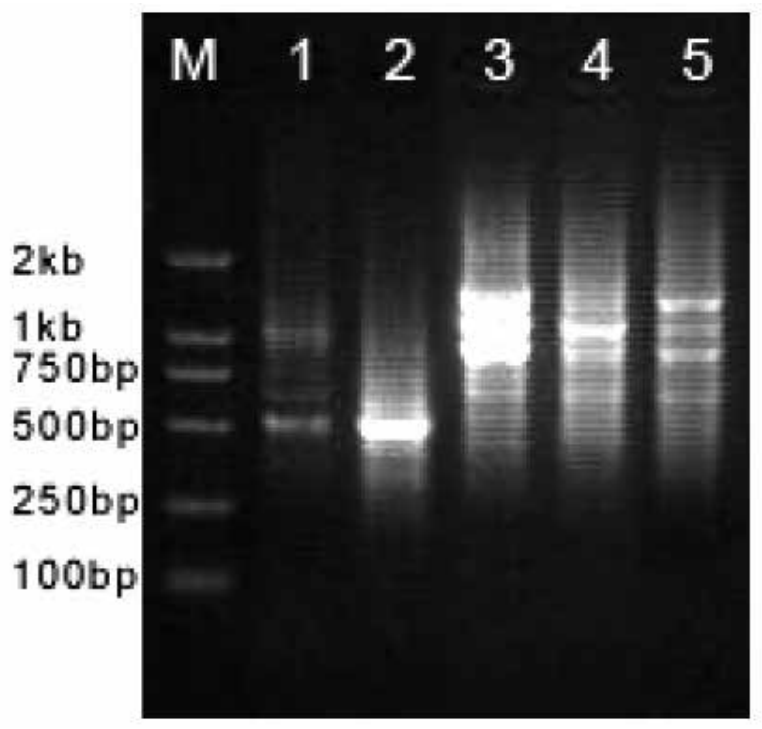

Figure 2. Secondary PCR products on $2 \%$ agarose gel. Lane M, DL-2000 marks; lane 1, subtracted tester cDNA for control subtraction; lane 2, unsubtracted tester cDNA for control subtraction; lane 3, control subtracted cDNA (provided by the kit); lane 4, subtracted cDNA; lane 5, unsubtracted cDNA.

Productos secundarios en gel de agarosa $2 \%$. Carril M, , marcas DL-2000; carril 1, cADN de probador sustraído para sustracción control; carril 2, cADN de probador sustraído para sustracción control; carril 3, cADN de control sustraído (proporcionado en el kit); carril 4, cADN sustraído; carril 5, cADN no sustraído.
REAL-TIME PCR ANALYSIS

To analyse the expression profiles of the SSH identified genes within the 4-week period of stimulation with LPS, real-time RT-PCR analysis was performed in the head kidney. The specificity of the RT-PCR products was documented using high-resolution gel electrophoresis. All genes resulted in a single product with the desired length.

\section{DISCUSSION}

Antibacterial, lysozyme and phenoloxidase activities were significantly increased when crab Scylla paramamosain was challenged with bacterial LPS (Nya and Austin 2010, Gopalakrishnan et al 2011). The results of this study showed that LPS had a similar effect on Malabar grouper and could be a potential effective immunostimulant for it.

Interferon regulatory factors (IRFs) can effectively combine with the promoter of the interferon (IFN) gene and thus induce and/or regulate IFN gene expression ${ }^{2}$ (Mamane et al 1999). Although IRF-2 can activate the expression of many genes, it is usually considered an inhibitory factor

2 Lehtonen A. 2005. Expression and activation of STAT and IRF family transcription factors in mononuclear leukocytes. Doctoral Dissertation, http://ethesis.helsinki.fi/julkaisut/bio/bioja/vk/lehtonen/, University of Helsinki, Finland.

Table 2. Differentially expressed genes detected in the head kidney cDNA of LPS-stimulated Epinephelus malabaricus.

Genes expresados diferencialmente detectados en el cADN de riñón cefálico en Epinephelus malabaricus estimulado con LPS.

\begin{tabular}{|c|c|c|c|c|c|c|}
\hline $\begin{array}{l}\text { Clone } \\
\text { number }\end{array}$ & Putative identification [Closest species] & $\begin{array}{l}\text { Accession } \\
\text { number }\end{array}$ & $\begin{array}{l}\text { Accession number } \\
\text { of closest species }\end{array}$ & E-Value & Identity & Frequency \\
\hline $\mathrm{C} 5$ & $\begin{array}{l}\text { Genes related to immune / defense } \\
\text { Interferon regulatory factor 2-binding protein 2-A } \\
\text { [Salmo salar }]\end{array}$ & GT067256 & \multirow[t]{2}{*}{$\begin{array}{l}\text { reflNP_001133325.1 } \\
\text { gb|AY823273.11 }\end{array}$} & $3 e-15$ & $94 \%$ & 4 \\
\hline D153 & T-complex protein 1-theta [Notothenia coriiceps] & GT067257 & & $2 \mathrm{e}-101$ & $88 \%$ & 1 \\
\hline $\mathrm{C} 130$ & $\begin{array}{l}\text { Genes related to oxygen transport } \\
\text { Haemoglobin beta chain [Epinephelus coioides] } \\
\text { Haemoglobin alpha chain [Thunnus thynnus] }\end{array}$ & GT067259 & gblAAK38736.1l & $5 e-72$ & $97 \%$ & 268 \\
\hline D34 & Ferritin heavy chain $[$ Psetta maxima $]$ & GT067260 & gblAAK38736.1l & $2 e-53$ & $72 \%$ & 9 \\
\hline E45 & & GT067261 & gblADI24353.1| & $1 \mathrm{e}-05$ & $96 \%$ & 1 \\
\hline $\mathrm{C} 34$ & $\begin{array}{l}\text { Genes related to transcription and translation } \\
\text { Eukaryotic translation elongation factor } 2 \text { [Danio } \\
\text { rerio] }\end{array}$ & GT067262 & gblABJ98666.1l & $4 e-59$ & $84 \%$ & 4 \\
\hline F39 & $\begin{array}{l}\text { Procollagen C-endopeptidase enhancer precursor } \\
\text { [Salmo salar }]\end{array}$ & GT067263 & gb|ACQ58156.11 & $8 e-66$ & $85 \%$ & 8 \\
\hline F22 & $\begin{array}{l}\text { Ribosomal protein S8 [Solea senegalensis] } \\
\text { Ribosomal protein L3 [Solea senegalensis] }\end{array}$ & GT067276 & dbj|BAF45896.1l & $7 e-48$ & $100 \%$ & 1 \\
\hline C136 & 40 S ribosomal protein S28 [Danio rerio] & GT067268 & dbj|BAF98579.1l & $3 e-135$ & $93 \%$ & 4 \\
\hline E26 & & GT067269 & reflNP_998199.1l & $3 e-21$ & $94 \%$ & 1 \\
\hline G129 & $\begin{array}{l}\text { Genes related to metabolism } \\
\text { CT054 protein [Salmo salar] }\end{array}$ & GT067264 & reflNP_001133955.1| & $2 e-76$ & $82 \%$ & 1 \\
\hline E112 & $\begin{array}{l}\text { Other genes } \\
\text { Myeloid leukemia differentiation protein homo- } \\
\text { logue [Salmo salar] }\end{array}$ & GT067265 & $\begin{array}{l}\text { reflNP_001117034.1| } \\
\text { reflNP_001074099.1| }\end{array}$ & $9 e-22$ & $79 \%$ & 8 \\
\hline E108 & $\mathrm{G}$ patch domain-containing protein 3 [Danio rerio] & GT067267 & & $5 e-64$ & $75 \%$ & 2 \\
\hline \multicolumn{4}{|l|}{ Unknown } & & & 14 \\
\hline
\end{tabular}


of IFN. IRF-2 could regulate an abnormal IFN response, maintain a constant IFN level in vivo in animals, and avoid the inflammatory response caused by excessive expression of IFN (Tanaka et al 1993, Vaughan et al 1995, Chung and Kawamoto 2004). Barber et al (1995) demonstrated that IRF-related gene expression might represent a molecular pathway involved in the response to LPS. Clone C5 (GT067256) in our SSH library had 94\% similarity to interferon regulatory factor 2-binding protein 2-A of Salmo salar. Therefore, it is presumed that an appropriate dose of LPS could induce the expression of IRF-binding protein in Malabar grouper, which might be related to maintaining a constant IFN level. Another immune-related gene, the T-complex protein 1-theta gene (GT067257) (Yin et al 1999, Izzotti et al 2003), was also obtained in this study. The results provided direct molecular evidence to explain why Malabar grouper showed strong innate immunity 28 days after LPS stimulation.

Haemoglobin $\beta$-chain gene, haemoglobin $\alpha$-chain gene, and the ferritin heavy chain $(f h c)$ gene were reported to contribute to oxidative stress resistance and apoptosis in vertebrates and invertebrates (Connie and Hsia 1998, Orino et al 2001, Larade and Storey 2004, Aung et al 2007). They were cloned in the SSH library of chickens infected with an avian leukosis virus subgroup (Zhao et al 2010). Moreover, Parish et al (2001) proved that haemoglobin (the intact tetramer of $\alpha$-chain or/and $\beta$-chain) had the roles of oxygen transportation and was an important multi-defense agent against a wide range of microorganisms in snake, alligator, horse and human. In this study, haemoglobin $\beta$-chain gene, haemoglobin $\alpha$-chain gene, and the ferritin heavy chain $(f h c)$ gene were also cloned in the SSH library of Malabar grouper. It elucidated that these three genes could be differentially expressed after the animal was stimulated by a special foreign substance, and LPS might enhance the non-specific immunity of Malabar grouper by up-regulation of haemoglobins and $f h c$.

The $\alpha$-ketoglutarate dehydrogenase is responsible for the conversion of $\alpha$-ketoglutarate to succinyl coenzyme A, an important energy-producing step in citric acid (TCA) cycle. The TCA cycle-related gene sucA (CT054) can down-regulate $\alpha$-ketoglutarate dehydrogenase activity (Belland et al 2003, Nicholson et al 2004 ). In this SSH library of Malabar grouper, one clone was the homological sequence (GT067264) to CT054, and five gene fragments related to transcription and translation (GT067262, GT067263, GT067276, GT067268, and GT067269) were also found. Interestingly, similar results were reported in some recent papers. For example, Micheluccia et $^{3} \mathrm{l}^{3}$ revealed that LPS stimulation can up-regulate itaconic acid(from the TCA cycle intermediate cisaconitate) synthesis in macrophages.

Micheluccia et al 2013. Immune-responsive gene 1 protein links metabolism to immunity by catalyzing itaconic acid production. Proc Natl Acad Sci USA Early Edition, www.pnas.org/cgi/doi/10.1073/ pnas. 1218599110.
These results showed that LPS might regulate metabolism and gene expression at transcriptional and/or translational levels. However, more experiments should be performed to confirm these immunity-related changes.

Procollagen C-endopeptidase enhancer ( $p c p e$ ) can regulate the level of high-density lipoprotein (HDL) particles in vivo (Zhu et al 2009). HDL particles have the function of anti-inflammatory, anti-aggregative and antioxidant properties (Stein and Stein 1999, Fredenrich and Bayer 2003). Walker et al (2003) proved that HDL particles played an important role on crustacean immune recognition mechanisms. Pajkrt et al (1996) also found that HDL particles could neutralise LPS stimulated activity in vitro and in vivo. The fact that the pcpe gene fragment (GT067263) was obtained in this study indicated that pcpe gene expression was an adaptive response of Malabar grouper to LPS.

The myeloid leukemia differentiation protein homologue is relevent to human leukemia and cell cycle regulation (Bürger et al 1994, Sen et al 1997). Gariglio et al (1998) reported that LPS could induce cells of the myeloid/ monocyte lineage to constitutively express p202 and p204 proteins, which belong to myeloid leukemia differentiation protein homologue group, and thus could slow down cell proliferation and regulate cell growth and differentiation. In this study, a gene fragment encoding myeloid leukemia differentiation protein homologue (GT067265) was obtained, which indicated that LPS might affect growth rate to some extent in Malabar grouper.

Haemoglobin $\beta$-chain gene was the most frequently identified clones (10.05\% of total clones) in this $\mathrm{SSH}$ library of Malabar groupe. This is probably because of the incomplete subtraction of Haemoglobin $\beta$-chain gene cDNA in the tester, which was due to the multifold amount of mRNA in the tester compared with the driver. However, this would not affect the differential display of the specific expressed genes in the tester. On the contrary, the up-regulation of the genes was better illustrated.

\section{ACKNOWLEDGEMENTS}

This work was supported by grants from the National Natural Science Foundations of China (Nos.30660144, 30760190, 31060360 and 31260644), the National Marine Public Welfare Research Project of China (No. 201205025), Specialized Research Fund for the Doctoral Program of Higher Education(No. 20124601110006) and the Project of Fok Ying Tong Education Foundation (No. 121030).

\section{REFERENCES}

Ashida M. 1971. Purification and characterization of pre-phenoloxidase from hemolymph of the silkworm, Bombyx mori. Arch Biochem Biophys 144, 749-762.

Aung W, S Hasegawa, T Furukawa, T Saga. 2007. Potential role of ferritin heavy chain in oxidative stress and apoptosis in human mesothelial and mesothelioma cells: implications for asbestos-induced oncogenesis. Carcinogenesis 28, 2047-2052.

Barber SA, MJ Fultz, CA Salkowski, SN Vogel. 1995. Differential expression of interferon regulatory factor 1 (irf-1), irf-2, and interferon 
consensus sequence binding protein genes in lipopolysaccharide (LPS)-responsive and LPS-hyporesponsive macrophages. Infect Immun 63, 601-608.

Belland BJ, DE Nelson, D Virok, DD Crane, D Hogan, D Sturdevant, WL Beatty, HD Caldwell. 2003. Transcriptome analysis of chlamydial growth during IFN- $\gamma$-mediated persistence and reactivation. Proc Natl Acad Sci USA 100, 15971-15976.

Bürger C, M Wick, R Müller. 1994. Lineage-specific regulation of cell cycle gene expression in differentiating myeloid cells. J Cell Sci 107, 2047-2054.

Chung MC, S Kawamoto. 2004. IRF-2 is involved in up-regulation of nonmuscle myosin heavy chain II-A gene expression during phorbol ester-induced promyelocytic HL-60 differentiation. $J$ Biol Chem 279, 56042-56052.

Connie CW , MD Hsia. 1998. Respiratory function of haemoglobin. $N$ Engl J Med 338, 239-248.

Diatchenko L, YF Lau, AP Campbell, A Chenchik, F Moqadam, B Huang, S Lukyanov, K Lukyanov, N Gurskaya, ED Sverdlov, PD Siebert. 1996. Suppression subtractive hybridization: a method for generating differentially regulated or tissue-specific cDNA probes and libraries. Proc Natl Acad Sci USA 93, 6025-6030.

Fredenrich A, P Bayer. 2003. Reverse cholesterol transport, high density lipoproteins and HDL cholesterol: recent data. Diabetes Metab 29, 201-205.

Gabriëls SH, FL Takken, JH Vossen, CF de Jong, Q Liu, SC Turk, LK Wachowski, J Peters, HM Witsenboer, PJ de Wit, MH Joosten. 2006. cDNA-AFLP combined with functional analysis reveals novel genes involved in the hypersensitive response. Mol Plant microbe In 19, 567-576.

Gariglio M, M De Andrea, M Lembo, M Ravotto, C Zappador, G Valente, S Landolfo. 1998. The murine homolog of the HIN 200 family, Ifi 204, is constitutively expressed in myeloid cells and selectively induced in the monocyte/macrophage lineage. J Leukoc Biol 64, 608-614.

Gopalakrishnan S, FY Chen, H Thilagam, K Qiao, WF Xu, KJ Wang. 2011. Modulation and interaction of immune-associated parameters with antioxidant in the immunocytes of crab Scylla paramamosain challenged with lipopolysaccharides. Evid-Based Compl Alt 2011, 1-8.

Gundogmaz G, S Dogan, O Arslan. 2003. Some kinetic properties of polyphenol oxidase obtained from various salvia species (Salvia viridis L., Salvia virgata Jacq. and Salvia tomentosa Miller). Food Sci Technol Int 9, 309-315.

Izzotti A, RM Balansky, C Cartiglia, A Camoirano, M Longobardi, S De Flora. 2003. Genomic and transcriptional alterations in mouse fetus liver after transplacental exposure to cigarette smoke. Faseb $J 17,1127-1129$.

Jian JC, JM Ye, ZH Wu. 2004. Influence of lipopolysaccharide from Vibrio alginolyticus on immunological function of Epinephelus Skaara. Acta Hydrob Sin 28, 103-105.

Larade K, KB Storey. 2004. Accumulation and translation of ferritin heavy chain transcripts following anoxia exposure in a marine invertebrate. J Exp Biol 207, 1353-1360.

Liang P, AB Pardee. 1992. Differential display of eukaryotic messenger RNA by means of the polymerase chain reaction. Science 257, 967-971.

Lin MF, SY Shiau. 2005. Dietary 1-ascorbic acid affects growth, nonspecific immune responses and disease resistance in juvenile grouper, Epinephelus malabaricus. Aquaculture 244, 215-221.

Lisitsyn N, M Wigler. 1993. Cloning the differences between two complex genomes. Science 259, 946-951.

MacKenzie S, JV Planas, FW Goetz. 2003. LPS-stimulated expression of a tumor necrosis factor-alpha mRNA in primary trout monocytes and in vitro differentiated macrophages. Dev Comp Immunol 27, 393-400.

Mamane Y, C Heylbroeck, P Génin, M Algarté, MJ Servant, C LePage, C DeLuca, H Kwon, R Lin, J Hiscott. 1999. Interferon regulatory factors: the next generation. Gene 237, 1-14.

Micheluccia A, T Cordesa, J Ghelfia, A Pailota, N Reilingb, O Goldmannc, T Binza, A Wegnera, A Tallama, A Rausella, M Buttinia, CL Linstera,
E Medinac, R Ballin, K Hiller. 2013. Immune-responsive gene 1 protein links metabolism to immunity by catalyzing itaconic acid production. Proc Natl Acad Sci USA 110, 7820-7825.

Neumann NF, D Fagan, M Belosevic. 1995. Macrophage activating factor(s) secreted by mitogen stimulated goldfish kidney leucocytes synergies with bacterial lipopolysaccharide to induce nitric oxide production in teleost macrophages. Dev Comp Immunol 19, 475-482.

Nicholson TL, K Chiu, RS Stephens. 2004. Chlamydia trachomatis lacks an adaptive response to changes in carbon source availability. Infect Iттии 72, 4286-4289.

Noga EJ, DP Engel, TW Arroll, S Mckenna, M Davidian. 1994. Low serum antibacterial activity coincides with increased prevalence of shell disease in blue crabs Callinectes sapidus. Dis Aquat Organ 19, 121-128.

Nya EJ, B Austin. 2010. Use of bacterial lipopolysaccharide (LPS) as an immunostimulant for the control of Aeromonas hydrophila infections in rainbow trout Oncorhynchus mykiss (Walbaum). J App Microb 108, 686-694.

Orino K, L Lehman, Y Tsuji, H Ayaki, SV Torti, FM Torti. 2001. Ferritin and the response to oxidative stress. Biochem J 357, 241-247.

Pajkrt D, JE Doran, E Koster, PG Lerch, B Arnet, T van der Poll, JW ten Cate, SJ van Deventer. 1996. Antiinflammatory effects of reconstituted high-density lipoprotein during human endotoxemia. J Exp Med 184, 1601-1608.

Parish CA, H Jiang, Y Tokiwa, N Berova, K Nakanishi, D McCabe, W Zuckerman, MM Xia, JE Gabay. 2001. Broad-spectrum antimicrobial activity of hemoglogin. Bioorg Med Chem 9, 377-382.

Parry RM, RC Chandon, KM Shahank. 1965. A rapid and sensitive assay of muramidase. Proc Soc Exp Biol Med 119, 384-386.

Perucho M, J Welsh, MA Peinado, Y Ionov, M McClelland. 1995. Fingerprinting of DNA and RNA by arbitrarily primed polymerase chain reaction: applications in cancer research. Method Enzymol 254, 275-290.

Savan R, M Sakai. 2002. Analysis of expressed sequence tags (EST) obtained from common carp, Cyprinus carpio L., head kidney cells after stimulation by two mitogens, lipopolysaccharide and concanavalin-A. Comp Biochem Phys B 131, 71-82.

Sen S, H Zhou, T Ripmaster, WN Hittelman, P Schimmel, RA White. 1997. Expression of a gene encoding a tRNA synthetase-like protein is enhanced in tumorigenic human myeloid leukemia cells and is cell cycle stage- and differentiation-dependent. Proc Natl Acad Sci USA 94, 6164-6169.

Stein O, Y Stein. 1999. Atheroprotective mechanisms of HDL. Atherosclerosis $144,285-303$

Tanaka N, T Kawakami, T Taniguchi. 1993. Recognition DNA sequences of interferon regulatory factor 1 (IRF-1) and IRF-2, regulators of cell growth and the interferon system. Mol Cell Biol 13, 4531-4538.

Tuan LA, KC Williams. 2007. Optimum dietary protein and lipid specifications for juvenile malabar grouper (Epinephelus malabaricus). Aquaculture 267, 129-138.

Vaughan PS, F Aziz, AJ van Wijnen, S Wu, H Harada, T Taniguchi, KJ Soprano, JL Stein, GS Stein. 1995. Activation of a cell-cycle-regulated histone gene by the oncogenic transcription factor IRF-2. Nature 377, 362-365.

Walker A, S Ando, RF Lee. 2003. Synthesis of a high-density lipoprotein in the developing blue crab (Callinectes sapidus). Biol Bull 204, 50-56.

Wang L, XZ Wu. 2007. Identification of differentially expressed genes in lipopolysaccharide-stimulated yellow grouper Epinephelus awoara spleen. Fish Shellfish Immun 23, 354-363.

Xu XD, ZY Xie, SF Wang, XZ Xuan, YC Zhou. 2010. Toxicity and immunogenicity of LPS from pathogenic Vibrio alginolyticus to grouper, Epinephelus malabaricus. Marine Sci 3, 47-51.(In Chinese).

Yin Z, JY He, Z Gong, TJ Lam, YM Sin. 1999. Identification of differentially expressed genes in Con A activated Carp Cyprinus carpio L. leucocytes. Comp Biochem Phys 124, 41-50.

Zhang B, W Lin, YJ Wang, RL Xu. 2010. Effects of artificial substrates on growth, spatial distribution and non-specific immunity factors of Litopenaeus vannamei in the intensive culture condition. Turk $J$ Fish Aquat Sci 10, 491-497. 
Zhao GP, MQ Zheng, JL Chen, J Wen, CM Wu, W Li, L Liu, Y Zhang. 2010. Differentially expressed genes in a flock of Chinese localbreed chickens infected with a subgroup avian leukosis virus using suppression subtractive hybridization. Genet Mol Biol 33, 44-50.
Zhu J, J Gardner, CR Pullinger, JP Kane, JF Thompson, OL Francone. 2009. Regulation of apolipoprotein $\mathrm{AI}$ (apoAI) processing by procollagen C-proteinase enhancer-2 (PCPE2) and bone morphogenetic protein-1 (BMP-1) [EB/OL]. J Lipid Res 50, 1257-1258. 